\title{
Classification of strains of Xanthomonas oryzae on the basis of their susceptibility against bacteriophages.
}

\author{
Satoshi WAкIмото*
}

\section{Introduction}

The bacteriophage for Xanthomonas oryzae (Uyeda et Ishiyama) Dowson, the agent attacking the pathogen of the bacterial leaf blight disease of rice, was at first isolated by Yoshii and others ${ }^{17}$ ) in 1953 from diseased paddy soil in Fukuoka prefecture, Japan. Some characteristics of this phage, named $\mathrm{OP}_{1}$, were previously reported by the author ${ }^{13)}$. A new bacteriophage $\mathrm{OP}_{1} h$ was then isolated by Tagami and others in 1958, and Ikari and the author ${ }^{4}$ confirmed that $\mathrm{OP}_{1} h$ had almost the same characteristics as $\mathrm{OP}_{1}$ except host range. Recently, Yoshimura and others ${ }^{18) 19)}$ reported that there were four kinds of phages, which differed from one another in host range or plaque shape, distributed in Hokuriku district, and that the host bacteria collected from the same district could be classified into 6 strains, $A, B, C, D, E$ and $A B$ according to the difference in susceptibility to these phages.

So as to contribute towards the practical applications $\left.{ }^{14}\right)^{15}$ ) of the phages, the susceptibility of many isolates of $X$. oryzae collected from various places of Japan to the phage strain widely distributed was tested.

\section{Material}

For the purpose of finding new phages, diseased leaves of the rice plant affected with $X$. oryzae were collected during an epidemic period from various places of Japan, as shown in Table 1.

Bacterial strains $X$. oryzae $22-\mathrm{SR}-2$ and $X$. oryzae $\mathrm{B}$ were employed to isolate the phages from each sample, because these bacterial strains were known to show exactly opposite susceptibility pattern with each other. The strain $22-\mathrm{SR}-2$ is susceptible to $\mathrm{OP}_{1}$ but not to $\mathrm{OP}_{1 h}$, while the strain $\mathrm{B}$ is susceptible to $\mathrm{OP}_{1 h}$ but not to $\mathrm{OP}_{1}$.

Every phages was isolated from single plaque produced on the culture plate of each bacterial strain. Many isolates of $X$. oryzae collected from various places of Japan were tested against the isolated phages as well as the standard phage strains of $\mathrm{OP}_{1}$, and $\mathrm{OP}_{2}$, in simultanious tests. The $\mathrm{OP}_{2}$ phage, which had been reported as SB phage by Yoshimura and others in 1959, was kindly furnished by him for this experiment.

The composition of the solid media used throughout the experiment was as follows; potato decoction $300 \mathrm{gr}$., $\mathrm{Na}_{2} \mathrm{HPO}_{4} \cdot 12 \mathrm{H}_{2} \mathrm{O} 2 \mathrm{gr}$., $\mathrm{Ca}\left(\mathrm{NO}_{3}\right)_{2} \cdot 4 \mathrm{H}_{2} \mathrm{O} 0.5 \mathrm{gr}$., sucrose $20 \mathrm{gr}$., peptone $5 \mathrm{gr}$. : water to $1 l$.

\section{Experimental methods}

Collected diseased leaves were cut finely by scissors, and $0.1 \mathrm{gr}$. of the sample was ground in a mortar with quartz sand and a few $\mathrm{ml}$. of distilled water. The suspension of each of the samples was then centrifuged at $12,000 \mathrm{rpm}$. for $10 \mathrm{~min}$. to remove the debris of leaf tissues and bacteria. The supernatant was diluted 100 -fold with sterilized distilled water, and either 0.1 or $0.01 \mathrm{ml}$. aliquats were poured into ca. $2 \mathrm{ml}$. of dense suspension of host bacteria which had been prepared just before. Three ml. of agar media which had been melted and kept at about $45^{\circ} \mathrm{C}$ was poured into each tube, and then the whole content of the tube was plated in Petri dish. Plate dishes thus prepared were incubated at $25^{\circ} \mathrm{C}$. Ten to 15 hours later, clear plaques appeared if phages in sufficient amount were contained in the original sample.

When plaques appeared on the plates of both B and 22-SR-2, the standard strains, it was concluded that the original sample contained either both $O P_{1}$ and $O P_{1}$, or it contained a new phage which attacked both bacterial strains. Many of the samples, in practice, produced plaques on the culture plates and were shown with temporary abbreviations in Table 1.

The host range of the phages were determined by using 82 isolates of $X$. oryzae, according to the following procedure. Each isolate cultured on agar slant at $25^{\circ} \mathrm{C}$ for 3 days was suspended in

\footnotetext{
* The author expresses his sincere gratitude to Dr. Mukoo for his valuable suggestions during the course
} of this work. 
Table 1. Distribution of $X$. oryzae phages in Japan.

\begin{tabular}{l|l|l|c}
\hline Places from which diseased leaves were collected & $\begin{array}{l}\text { Variety of rice plant } \\
\text { collected }\end{array}$ & Phage isolate \\
\hline Koga-gun & Shiga Pref. & Kinmaze & Kinmaze \\
Gamoo-gun & Shiga Pref. & Norin-mochi no. 5 & B2 \\
Aki-shi & Köchi Pref. & ? & D1 \\
Gifu-shi & Gifu Pref. & Hōkiasahi & E1 \\
Iwami-gun & Tottori Pref. & Tyugoku-mochi no. 11 & F1 \\
Kamimasuki-gun & Kumamoto Pref. & Norin no. 43 & G1, G2 \\
Niitsu-shi & Niigata Pref. & Sasashigure & H1 \\
Ōmagari-shi & Akita Pref. & Zikkoku & I1 \\
Mii-gun & Fukuoka Pref. & Zuiho & J2 \\
Kanoya-shi & Kagoshima Pref. & Wakabanishiki & K1 \\
Kōfu-shi & Yamanashi Pref. & ?1, L2 \\
Gifu-shi & Gifu Pref. & Kinmaze & M1, M2 \\
Nangoku-shi & Kōchi Pref. & Kyushu no. 58 & N1, N2 \\
Nangoku-shi & Kōchi Pref. & Shimotsuki & O1, O2 \\
Aki-shi & Kōchi Pref. & Zuikyu & P1, P2 \\
Aki-shi & Kōchi Pref. & Mihonishiki & Q1 \\
Kumage-gun & Yamaguchi Pref. & Kagabono & R1 \\
Ayauta-gun & Kawa Pref. & &
\end{tabular}

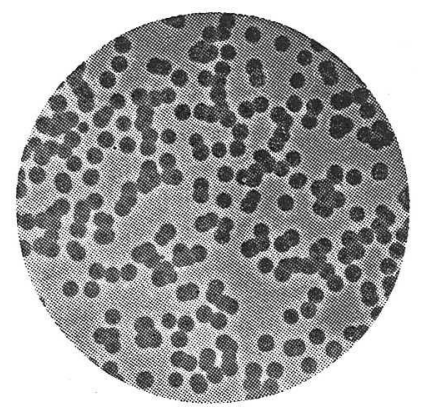

Fig. 1 Plaques of $\mathrm{OP}_{1}$ phage produced on $X$. oryzae No. 49 incubated at $25^{\circ} \mathrm{C}$ for 15 hours.

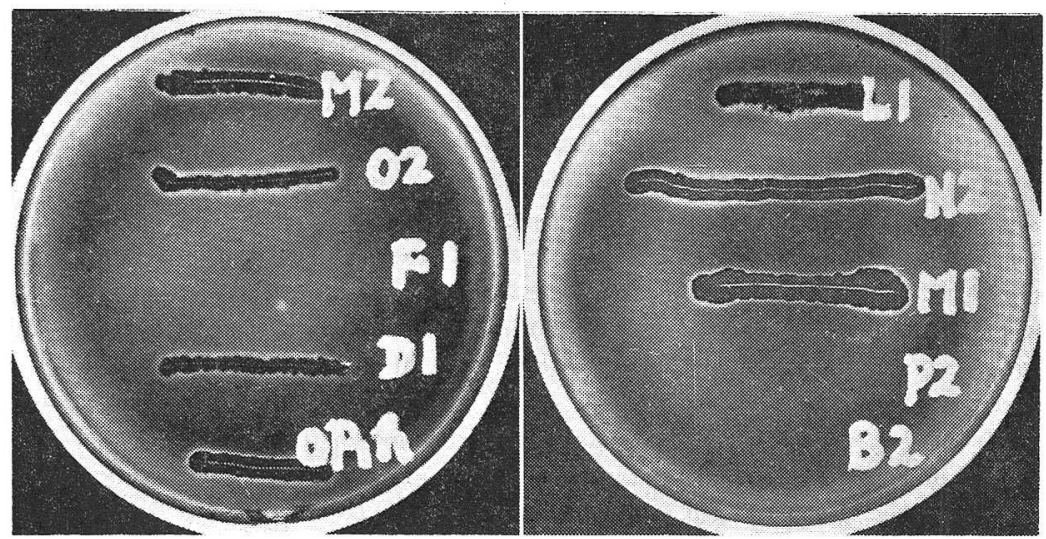

Fig. 2 Streak method to examine the reaction of an isolate of $X$. oryzae against a number of phage strains. 
$2 \mathrm{ml}$. of sterilized water. The bacterial suspensions thus prepared were mixed with ca. $3 \mathrm{ml}$. of melted $\left(45^{\circ} \mathrm{C}\right)$ potato semi-synthetic agar media, and poured into Petri dishes. After the plated agar settled, phage suspensions to be tested were streaked using a sterilized loop along the lines marked in parallel on the under surface of the sterilized dishes. After incubating the dishes at $25^{\circ} \mathrm{C}$ for 15 hours, clear streaks having some width appeared, if the plated bacteria are susceptible to the phages.

\section{Results}

1. Distribution of isolates of the bacteriophage for X. oryzae in Japan.

Most of the diseased leaves collected during an epidemic period contained some phages. The phages could be classified on the basis of their host range, as was shown in Table 2.

Table 2. Classification of $X$. oryzae phages from Japan.

\begin{tabular}{c|c} 
Strain of $X$. oryzae phage & $X$. oryzae phage isolate \\
\hline $\mathrm{OP}_{1}$ & $\mathrm{E} 1, \mathrm{~F} 1, \mathrm{G} 1, \mathrm{H} 1, \mathrm{I} 1, \mathrm{~K} 1, \mathrm{Q} 1, \mathrm{R} 1$ \\
$\mathrm{OP}_{1 h}$ & $\mathrm{~B} 2$ \\
$\mathrm{OP}_{1 h 2}$ & $\mathrm{C} 1, \mathrm{D} 1, \mathrm{G} 2, \mathrm{~J} 2, \mathrm{~L} 1, \mathrm{~L} 2, \mathrm{M} 1, \mathrm{M} 2, \mathrm{~N} 1, \mathrm{O} 1, \mathrm{O} 2, \mathrm{P} 1, \mathrm{P} 2,(\mathrm{~N} 2)$ \\
$\mathrm{OP}$ &
\end{tabular}

Probable reason for the higher frequency of isolation of $\mathrm{OP}_{1 h 2}$ than that of $\mathrm{OP}_{1}$ was that the diseased leaves employed in isolating the phages in this experiment were mostly collected from places from where $\mathrm{OP}_{1}$-resistant bacteria had been collected in preliminary experiments. Though $\mathrm{OP}_{2}$ phage was isolated by Yoshimura and others in 1958 from Hokuriku district, it was considered that the range of distribution of this phage was rather limitted from the results of this experiment in which $\mathrm{OP}_{2}$ was not found.

Whatever may be the reason, it seems likely that $O P_{1}$ and $O P_{1 h 2}$ have the more extensive distribution in Japan than $\mathrm{OP}_{1 h}$ or any other phages.

2. Susceptibility of the isolates of $X$. oryzae to the phages.

Eighty-two isolates of $X$. oryzae were tested for their susceptibility to each of the phages $\mathrm{OP}_{1}$, $\mathrm{OP}_{1 h}, \mathrm{OP}_{1 h 2}$, and $\mathrm{OP}_{2}$. The results were given in Table 3 .

Table 3. Reaction of isolate of $X$. oryzae against phages.

\begin{tabular}{|c|c|c|c|c|c|c|}
\hline \multirow{2}{*}{ Isolate } & \multirow{2}{*}{$\begin{array}{l}\text { Pref. from which } \\
\text { the diseased leaves } \\
\text { were collected }\end{array}$} & \multicolumn{4}{|c|}{ Strain of phage } & \multirow{2}{*}{$\begin{array}{l}\text { Strain classifi- } \\
\text { cation of } X . \\
\text { oryzae }\end{array}$} \\
\hline & & $\mathrm{OP}_{1}$ & $\mathrm{OP}_{1 h}$ & $\mathrm{OP}_{1 h 2}$ & $\mathrm{OP}_{2}$ & \\
\hline $\begin{array}{l}\text { N } 5801 \\
\text { N } 5802 \\
\text { N } 5803 \\
\text { N } 5804 \\
\text { N } 5805\end{array}$ & $\begin{array}{l}\text { Akita } \\
\text { Akita } \\
\text { Akita } \\
\text { Akita } \\
\text { Yamagata }\end{array}$ & $\begin{array}{l}- \\
\frac{-}{+} \\
-\end{array}$ & $\begin{array}{l}\overline{+} \\
\overline{+} \\
+\end{array}$ & $\begin{array}{l}- \\
+ \\
+ \\
+ \\
+\end{array}$ & $\begin{array}{l}+ \\
+ \\
+ \\
+ \\
+\end{array}$ & $\begin{array}{l}\text { E } \\
\text { B } \\
\text { A } \\
\text { B } \\
\text { B }\end{array}$ \\
\hline $\begin{array}{l}\text { N } 5806 \\
\text { N } 5807 \\
\text { N } 5808 \\
\text { N } 5809 \\
\text { N } 5810\end{array}$ & $\begin{array}{l}\text { Fukushima } \\
\text { Fukushima } \\
\text { Miyagi } \\
\text { Miyagi } \\
\text { Miyagi }\end{array}$ & $\begin{array}{l}+ \\
+ \\
+ \\
+ \\
-\end{array}$ & $\begin{array}{l}- \\
- \\
- \\
-\end{array}$ & $\begin{array}{l}+ \\
+ \\
+ \\
+ \\
+\end{array}$ & $\begin{array}{l}+ \\
+ \\
+ \\
+ \\
+\end{array}$ & $\begin{array}{l}\text { A } \\
\text { A } \\
\text { A } \\
\text { A } \\
\text { B }\end{array}$ \\
\hline $\begin{array}{l}\text { N } 5811 \\
\text { N } 5812 \\
\text { N } 5813 \\
\text { N } 5814 \\
\text { N } 5815\end{array}$ & $\begin{array}{l}\text { Miyagi } \\
\text { Miyagi } \\
\text { Ibaragi } \\
\text { Ibaragi } \\
\text { Ibaragi }\end{array}$ & $\begin{array}{l}- \\
+ \\
+ \\
+ \\
-\end{array}$ & $\begin{array}{l}- \\
\overline{-} \\
\overline{+} \\
+\end{array}$ & $\begin{array}{l}- \\
+ \\
+ \\
+ \\
+\end{array}$ & $\begin{array}{l}- \\
+ \\
+ \\
+ \\
+\end{array}$ & $\begin{array}{l}\mathrm{C} \\
\mathrm{A} \\
\mathrm{A} \\
\mathrm{A} \\
\mathrm{B}\end{array}$ \\
\hline $\begin{array}{l}\text { N } 5816 \\
\text { N } 5817 \\
\text { N } 5818 \\
\text { N } 5819 \\
\text { N } 5820\end{array}$ & $\begin{array}{l}\text { Ibaragi } \\
\text { Gunma } \\
\text { Kanagawa } \\
\text { Kanagawa } \\
\text { Saitama }\end{array}$ & $\begin{array}{l}- \\
+ \\
+ \\
+ \\
+\end{array}$ & $\begin{array}{l} \pm \\
- \\
- \\
-\end{array}$ & $\begin{array}{l}+ \\
+ \\
+ \\
+ \\
+\end{array}$ & $\begin{array}{l}+ \\
+ \\
+ \\
+ \\
+\end{array}$ & $\begin{array}{l}\mathrm{B} \\
\mathrm{A} \\
\mathrm{A} \\
\mathrm{A} \\
\mathrm{A}\end{array}$ \\
\hline $\begin{array}{l}\text { N } 5821 \\
\text { N } 5822 \\
\text { N } 5823 \\
\text { N } 5824 \\
\text { N } 5825\end{array}$ & $\begin{array}{l}\text { Saitama } \\
\text { Saitama } \\
\text { Chiba } \\
\text { Tokyo } \\
\text { Niigata }\end{array}$ & $\begin{array}{l}+ \\
+ \\
+ \\
+ \\
+\end{array}$ & $\begin{array}{l}\overline{-} \\
\overline{-} \\
-\end{array}$ & $\begin{array}{l}+ \\
+ \\
+ \\
+ \\
+\end{array}$ & $\begin{array}{l}+ \\
+ \\
+ \\
+ \\
+\end{array}$ & $\begin{array}{l}\text { A } \\
\text { A } \\
\text { A } \\
\text { A } \\
\text { A }\end{array}$ \\
\hline
\end{tabular}




\begin{tabular}{|c|c|c|c|c|c|c|}
\hline \multirow{2}{*}{ Isolate } & \multirow{2}{*}{$\begin{array}{l}\text { Pref. from which } \\
\text { the diseased leaves } \\
\text { were collected }\end{array}$} & \multicolumn{4}{|c|}{ Strain of phage } & \multirow{2}{*}{$\begin{array}{l}\text { Strain classifi- } \\
\text { cation of } X . \\
\text { oryzae }\end{array}$} \\
\hline & & $\mathrm{OP}_{1}$ & $\mathrm{OP}_{1 h}$ & $\mathrm{OP}_{1 h 2}$ & $\mathrm{OP}_{2}$ & \\
\hline $\begin{array}{l}\text { N } 5826 \\
\text { N } 5827 \\
\text { N } 5828 \\
\text { N } 5829 \\
\text { N } 5830\end{array}$ & $\begin{array}{l}\text { Fukui } \\
\text { Fukui } \\
\text { Fukui } \\
\text { Fukui } \\
\text { Fukui }\end{array}$ & $\begin{array}{l}- \\
- \\
+ \\
+\end{array}$ & $\begin{array}{l}+ \\
+ \\
+ \\
+ \\
+\end{array}$ & $\begin{array}{l}+ \\
+ \\
+ \\
+ \\
+\end{array}$ & $\begin{array}{l}+ \\
+ \\
+ \\
+ \\
+\end{array}$ & $\begin{array}{l}\mathrm{B} \\
\mathrm{B} \\
\mathrm{B} \\
\mathrm{A} \\
\mathrm{B}\end{array}$ \\
\hline $\begin{array}{l}\text { N } 5831 \\
\text { N } 5832 \\
\text { N } 5833 \\
\text { N } 5834 \\
\text { N } 5835\end{array}$ & $\begin{array}{l}\text { Ishikawa } \\
\text { Ishikawa } \\
\text { Toyama } \\
\text { Nagano } \\
\text { Nagano }\end{array}$ & $\begin{array}{l}- \\
\overline{+} \\
+ \\
+\end{array}$ & $\begin{array}{l}+ \\
- \\
-\end{array}$ & $\begin{array}{l}+ \\
+ \\
+ \\
+ \\
+\end{array}$ & $\begin{array}{l}+ \\
+ \\
+ \\
+ \\
+\end{array}$ & $\begin{array}{l}\text { B } \\
\text { D } \\
A \\
A \\
A\end{array}$ \\
\hline $\begin{array}{l}\text { N } 5836 \\
\text { N } 5837 \\
\text { N } 5838 \\
\text { N } 5839 \\
\text { N } 5840\end{array}$ & $\begin{array}{l}\text { Nagano } \\
\text { Yamanashi } \\
\text { Yamanashi } \\
\text { Yamanashi } \\
\text { Shiga }\end{array}$ & $\begin{array}{l}+ \\
+ \\
+ \\
-\end{array}$ & $\begin{array}{l}- \\
- \\
+ \\
-\end{array}$ & $\begin{array}{l}+ \\
+ \\
+ \\
+ \\
+\end{array}$ & $\begin{array}{l}+ \\
+ \\
+ \\
+ \\
+\end{array}$ & $\begin{array}{l}\text { A } \\
\text { A } \\
\text { A } \\
\text { B } \\
D\end{array}$ \\
\hline $\begin{array}{l}\text { N } 5841 \\
\text { N } 5842 \\
\text { N } 5843 \\
\text { N } 5844 \\
\text { N } 5845\end{array}$ & $\begin{array}{l}\text { Shiga } \\
\text { Shiga } \\
\text { Gifu } \\
\text { Gifu } \\
\text { Shizuoka }\end{array}$ & $\begin{array}{l}- \\
- \\
- \\
-\end{array}$ & $\begin{array}{l}+ \\
- \\
-\end{array}$ & $\begin{array}{l}+ \\
+ \\
+ \\
+\end{array}$ & $\begin{array}{l}+ \\
+ \\
+ \\
+ \\
+\end{array}$ & $\begin{array}{l}\mathrm{B} \\
\mathrm{E} \\
\mathrm{D} \\
\mathrm{D} \\
\mathrm{B}\end{array}$ \\
\hline $\begin{array}{l}\text { N } 5846 \\
\text { N } 5847 \\
\text { N } 5848 \\
\text { N } 5849 \\
\text { N } 5850\end{array}$ & $\begin{array}{l}\text { Nara } \\
\text { Hyogo } \\
\text { Hyogo } \\
\text { Ösaka } \\
\text { Okayama }\end{array}$ & $\begin{array}{l}+ \\
+ \\
+ \\
+ \\
+\end{array}$ & $\begin{array}{l}- \\
- \\
- \\
-\end{array}$ & $\begin{array}{l}+ \\
+ \\
+ \\
+ \\
+\end{array}$ & $\begin{array}{l}+ \\
+ \\
+ \\
+\end{array}$ & $\begin{array}{l}\mathrm{A} \\
\mathrm{A} \\
\mathrm{A} \\
\mathrm{A} \\
\mathrm{A}\end{array}$ \\
\hline $\begin{array}{l}\text { N } 5851 \\
\text { N } 5852 \\
\text { N } 5853 \\
\text { N } 5854 \\
\text { N } 5855\end{array}$ & $\begin{array}{l}\text { Okayama } \\
\text { Okayama } \\
\text { Hiroshima } \\
\text { Yamaguchi } \\
\text { Yamaguchi }\end{array}$ & $\begin{array}{l}+ \\
+ \\
+ \\
+ \\
-\end{array}$ & $\begin{array}{l}- \\
\overline{+} \\
\overline{+}\end{array}$ & $\begin{array}{l}+ \\
+ \\
+ \\
+ \\
+\end{array}$ & $\begin{array}{l}+ \\
+ \\
+ \\
+ \\
+\end{array}$ & $\begin{array}{l}\text { A } \\
\text { A } \\
\text { B } \\
\text { A } \\
\text { B }\end{array}$ \\
\hline $\begin{array}{l}\text { N } 5856 \\
\text { N } 5857 \\
\text { N } 5858 \\
\text { N } 5859 \\
\text { N } 5860\end{array}$ & $\begin{array}{l}\text { Yamaguchi } \\
\text { Yamaguchi } \\
\text { Yamaguchi } \\
\text { Shimane } \\
\text { Kagawa }\end{array}$ & $\begin{array}{l}- \\
+ \\
+ \\
+ \\
-\end{array}$ & $\begin{array}{l}+ \\
- \\
- \\
-\end{array}$ & $\begin{array}{l}+ \\
+ \\
+ \\
+ \\
-\end{array}$ & $\begin{array}{l}+ \\
+ \\
+ \\
+ \\
+\end{array}$ & $\begin{array}{l}\mathrm{B} \\
\mathrm{A} \\
\mathrm{A} \\
\mathrm{A} \\
\mathrm{C}\end{array}$ \\
\hline $\begin{array}{l}\text { N } 5861 \\
\text { N } 5862 \\
\text { N } 5863 \\
\text { N } 5864 \\
\text { N } 5865\end{array}$ & $\begin{array}{l}\text { Tokushima } \\
\text { Tokushima } \\
\text { Kōchi } \\
\text { Kōchi } \\
\text { Kōchi }\end{array}$ & $\begin{array}{l}- \\
\overline{+} \\
+ \\
-\end{array}$ & $\begin{array}{l}+ \\
+ \\
- \\
-\end{array}$ & $\begin{array}{l}+ \\
+ \\
+ \\
+ \\
-\end{array}$ & $\begin{array}{l}+ \\
+ \\
+ \\
+ \\
+\end{array}$ & $\begin{array}{l}\text { B } \\
\text { B } \\
\text { A } \\
\text { D } \\
\text { C }\end{array}$ \\
\hline $\begin{array}{l}\text { N } 5866 \\
\text { N } 5867 \\
\text { N } 5868 \\
\text { N } 5869 \\
\text { N } 5870\end{array}$ & $\begin{array}{l}\text { Kōchi } \\
\text { Kōchi } \\
\text { Fukuoka } \\
\text { Fukuoka } \\
\text { Fukuoka }\end{array}$ & $\begin{array}{l}- \\
- \\
+ \\
+\end{array}$ & $\begin{array}{l}- \\
- \\
- \\
-\end{array}$ & $\begin{array}{l}+ \\
+ \\
+ \\
+ \\
+\end{array}$ & $\begin{array}{l}+ \\
+ \\
+ \\
+ \\
+\end{array}$ & $\begin{array}{l}\mathrm{D} \\
\mathrm{D} \\
\mathrm{D} \\
\mathrm{A} \\
\mathrm{A}\end{array}$ \\
\hline $\begin{array}{l}\text { N } 5871 \\
\text { N } 5872 \\
\text { N } 5873 \\
\text { N } 5874 \\
\text { N } 5875\end{array}$ & $\begin{array}{l}\text { Saga } \\
\text { Saga } \\
\text { Saga } \\
\text { Saga } \\
\text { Saga }\end{array}$ & $\begin{array}{l}+ \\
+ \\
+ \\
- \\
+\end{array}$ & $\begin{array}{l}- \\
- \\
- \\
-\end{array}$ & $\begin{array}{l}+ \\
+ \\
- \\
+\end{array}$ & $\begin{array}{l}+ \\
+ \\
+ \\
+ \\
+\end{array}$ & $\begin{array}{l}\text { A } \\
\text { A } \\
\mathrm{E} \\
\mathrm{C} \\
\mathrm{A}\end{array}$ \\
\hline $\begin{array}{l}\text { N } 5876 \\
\text { N } 5877 \\
\text { N } 5878 \\
\text { N } 5879 \\
\text { N } 5880\end{array}$ & $\begin{array}{l}\text { Saga } \\
\text { Saga } \\
\text { Saga } \\
\text { Kumamoto } \\
\text { Kumamoto }\end{array}$ & $\begin{array}{l}+ \\
+ \\
+ \\
+ \\
+\end{array}$ & $\begin{array}{l}- \\
- \\
- \\
-\end{array}$ & $\begin{array}{l}+ \\
+ \\
+ \\
+ \\
+\end{array}$ & $\begin{array}{l}+ \\
+ \\
+ \\
+ \\
+\end{array}$ & $\begin{array}{l}\mathrm{A} \\
\mathrm{A} \\
\mathrm{A} \\
\mathrm{A} \\
\mathrm{A}\end{array}$ \\
\hline $\begin{array}{l}\text { N } 5881 \\
\text { N } 5882\end{array}$ & $\begin{array}{l}\text { Miyazaki } \\
\text { Kagoshima }\end{array}$ & $\overline{-}$ & \pm & + & $\begin{array}{l}+ \\
+\end{array}$ & $\begin{array}{l}\mathrm{B} \\
\mathrm{D}\end{array}$ \\
\hline
\end{tabular}

* Nos. of bacterial isolates, total and affected with the phage strains. 
$X$. oryzae could be divided into 5 strains $\mathrm{A}, \mathrm{B}, \mathrm{C}, \mathrm{D}$, and $\mathrm{E}$, as was shown in Table 4 . Most of the 82 isolates tested in this experiment belonged to A strain, and only a small number of them belonged to $\mathrm{B}, \mathrm{D}, \mathrm{C}$, or $\mathrm{E}$, in frequency in this order.

\section{Discussion}

Presence of several phage strains attacking the same phytopathogenic bacterial species was reported by several workers. Fulton ${ }^{3)}$ demonstrated that there are two $P$. tabaci phages, phage 1 and phage 2, attacking $P$. tabaci, and that these phages showed different host range and different particle shape. Okabe and others ${ }^{10) 11}{ }^{12}$ ) and Matsui ${ }^{7}$ also reported similar phenomena with $P$. solanacearum phages.

Present studies showed that the phages for $X$. oryzae distributed in Japan belonged either to $\mathrm{OP}_{1}$ group or to $\mathrm{OP}_{2}$ group. The $\mathrm{OP}_{1}$ group comprised several strains, $\mathrm{OP}_{1}, \mathrm{OP}_{1 h}, \mathrm{OP}_{1 h 2}$, and $\mathrm{OP}_{1 t}$, while the $\mathrm{OP}_{2}$ group comprised only one strain. From the results of morphological studies using electronmicroscope, it was found that phages of both these group had tadpole shape, but they differ in the size of tail : the former had a head of $70 \mathrm{~m} \mu$ in diameter with a tail of $150 \mathrm{~m} \mu$ in length and $15 \mathrm{~m} \mu$ in width, while the latter had a head of the same diameter with a tail of $95 \mathrm{~m} \mu$ in length and $25 \mathrm{~m} \mu$ in width. Furthermore some differences in serological properties was found between $\mathrm{OP}_{1}$ group and $\mathrm{OP}_{2}$ by Yoshimura and others ${ }^{19}$.

Classification of the strains of phytopathogenic bacteria on the basis of the susceptibility to phage together with some biological characteristics was first reported by Okabe and others in $1953 . \quad$ Recently, Yoshimura ${ }^{18}$ ) reported that $X$. oryzae collected from Hokuriku district could be classified into 6 strains, $\mathrm{A}, \mathrm{B}, \mathrm{C}, \mathrm{D}, \mathrm{E}$, and, $\mathrm{AB}$, based on the susceptibility to 4 strains of phage. I phage which was a plaque shape mutant of $\mathrm{OP}_{2}$, used in his experiment instead of $\mathrm{OP}_{1}$, seemed to be questionable, inasmuch as the more confusion of the classification was resulted.

Random distribution of various phage strains which differ in host range, in a company with that of various strains of $X$. oryzae which differ in susceptibility to the phages, present a problem in the practical use of the phages, particularly for the diagnosis, bacterial leaf blight of rice, or for the forecasting of the disease outbreaks. Practically, it will be necessary to select the phage and the bacterial strains, for the purpose of determining bacterial population, or assaying phage titre, in the field.

Between the pathogenicity of the host bacterial strains and their phage-susceptibility, relationship was not found according to this results joined with that obtained from the infection experiments ${ }^{9)}$ carried out simultaneously.

\section{Summary}

Xanthomonas oryzae bacteriophage collected from various places of Japan could be classified into 4 strains, $\mathrm{OP}_{1}, \mathrm{OP}_{1 h}, \mathrm{OP}_{1 h 2}$ and $\mathrm{OP}_{2}$ on the basis of their host range. It appeared that $\mathrm{OP}_{1}$ and $\mathrm{OP}_{1 \mathrm{k} 2}$ were the ones more extensively distributed than the other phage strains in Japan.

On the basis of susceptibility to these phage strains, 82 isolates of $X$. oryzae collected from various places of Japan were classified into 5 strains as follows ;

A strain : Susceptible to $\mathrm{OP}_{1}, \mathrm{OP}_{1 h 2}$ and $\mathrm{OP}_{2}$ but not to $\mathrm{OP}_{1 h}$

$\mathrm{B}$ strain : Susceptible to $\mathrm{OP}_{1 h}, \mathrm{OP}_{1 h 2}$ and $\mathrm{OP}_{2}$ but not to $\mathrm{OP}_{1}$

C strain : Resistant to all of these phages

D strain : Susceptible to $\mathrm{OP}_{1 h_{2}}$ and $\mathrm{OP}_{2}$ but not to $\mathrm{OP}_{1}$ and $\mathrm{OP}_{1 h}$

E strain : Susceptible to $\mathrm{OP}_{2}$ but not to $\mathrm{OP}_{1}, \mathrm{OP}_{1 h}$ and $\mathrm{OP}_{1 h 2}$

Of these bacterial strains, A strain was the one most widely and commonly distributed in Japan, followed by B, D, C, and E strains in decending order. There was found no specific rule in the distribution pattern of these strains.

(National Institute of Agricultural Sciences, Tokyo, Japan)

(Received Sept. 15, 1960)

\section{References}

1) Adams, M. H. (1950). Method of Study of Bacterial Viruses, in "Method in Medical Research" 2, The Year Book Publishers, Cicago.

2) Adams, M. H. (1959). Bacteriophages, Interscience Publishers, Inc., New York.

3 ) Fulton, R. W. (1950). Phytopath., $40: 936 \sim 949$. 
4) Ikari, H. and. Wakimoto S. (1958). Proc. Assoc. Plant Protection, Kyushu, $4: 38 \sim 40$.

5 ) Klement, Z. and Lovas, B. (1960). Phytopath. Zeitsch., $37: 321 \sim 329$.

6) Klement, Z. (1959). Nature, $184: 1248 \sim 1249$.

7 ) Matsui, C. (1953). Sci. Bul. Fac. Agr., Kyushu Univ., $14: 43 \sim 49$.

8 ) Matsui, C. (1955). Sci. Bul. Fac. Agr., Kyushu Univ., $15: 333 \sim 338$.

9 ) Mukoo, H., Kusaba, T., Watanabe, M., Wakimoto, S., and Yamazaki, Y. (unpublished)

10 ) Okabe, N. and Goto, M. (1952). Rept. Fac. Agr., Shizuoka Univ., $2: 64 \sim 93$.

11 ) Okabe, N. and Goto, M. (1953). Rept. Fac. Agr., Shizuoka Univ., $3: 52 \sim 80$.

12) Okabe, N. and Goto, M. (1953). Rept. Fac. Agr., Shizuoka Univ., $3: 81 \sim 100$.

13) Wakimoto, S. (1954). Sci. Bul. Fac. Agr., Kyushu Univ., $14: 485 \sim 493$.

14) Wakimoto, S. (1954). Sci. Bul. Fac. Agr., Kyushu Univ., $14: 495 \sim 498$.

15) Wakimoto, S. and Yoshii, H. (1955). Sci. Bul. Fac. Agr., Kyushu Univ., $15: 161 \sim 169$.

16) Wakimoto, S. (1955). Sci. Bul. Fac. Agr., Kyushu Univ., $15: 151 \sim 160$.

17 ) Yoshii, H., Yoshida, T. and Matsui, C. (1953). Ann. Phytopath. Soc., Japan, $17: 117$ (abst.).

18) Yoshimura, S., Morihashi, T. and Nakaomi, Y. (1959). Proc. Assoc. Plant Protection, Hokuriku, $7: 53 \sim 55$.

19) Yoshimura, S. Personal communication.

和文摘要

$$
\begin{gathered}
\text { バクテリオファージに対する感受性による } \\
\text { イネ白葉枯病菌の分類 }
\end{gathered}
$$

脇 本 哲

日本の各地から収集したイネ白葉枯病菌フォージは, それらの寄主範囲から, $\mathrm{OP}_{1}, \mathrm{OP}_{1 h}, \mathrm{OP}_{1 h 2}, \mathrm{OP}_{2}$ の 4 系 統に分類できる。これらの内, $\mathrm{OP}_{1}$ と $\mathrm{OP}_{1 h 2}$ とが最も広く分布しているようである。

また日本の各地から集めたイネ白葉枯病菌の分離地別 82 采統菌は, ファージに対する感受性から次の5 采統 に分類できる。

系統 $\mathrm{A}: \mathrm{OP}_{1}, \mathrm{OP}_{1 h 2}, \mathrm{OP}_{2}$ に感受性で $\mathrm{OP}_{1 h}$ に抵抗性

系統 $\mathrm{B}: \mathrm{OP}_{1 h}, \mathrm{OP}_{1 h 2}, \mathrm{OP}_{2}$ に感受性で $\mathrm{OP}_{1}$ に抵抗性

系統 C : 寸べてのファージに抵抗性

系統 D : $\mathrm{OP}_{1 h 2}, \mathrm{OP}_{2}$ に感受性で $\mathrm{OP}_{1}, \mathrm{OP}_{1 h}$ に抵抗性

系統 $\mathrm{E}: \mathrm{OP}_{2}$ に感受性で $\mathrm{OP}_{1}, \mathrm{OP}_{1 h}, \mathrm{OP}_{1 h 2}$ に抵抗性

これらのイネ白葉枯病菌柔統の内, 日本における分布は系統 Aが最も広く, ついで $\mathrm{B}, \mathrm{D}, \mathrm{C}, \mathrm{E}$ の順である、 しかしながら,これらの香統の分布模様には規則性は諗められない。 